\title{
The separation of the influence of nutrients and climate on the varve time-series of Baldeggersee, Switzerland
}

\author{
A. F. Lotter ${ }^{1}$ and H. J. B. Birks ${ }^{2}$ \\ 1 University of Bern, Geobotanical Institute, Altenbergrain 21, CH-3013 Bern, Switzerland, \\ and Swiss Federal Institute for Environmental Science and Technology (EAWAG), \\ CH-8600 Dübendorf, Switzerland \\ 2 University of Bergen, Botanical Institute, Allégaten 41, N-5007 Bergen, Norway; \\ and Environmental Change Research Centre, Dept. of Geography, University College \\ London, 26 Bedford Way, London WC1H 0AP, UK
}

Key words: Variance partitioning, redundancy analysis, multiple linear regression, eutrophication, varves.

\begin{abstract}
The varve data-set from a freeze-core taken in the deepest part of Baldeggersee was subjected to different multivariate statistical analyses in order to estimate the amount of variance in the varve thickness measures explicable by past climate and by the trophic state of the lake. A comparison of two different time-periods (1902 to 1992 versus 1920 to 1980) revealed that the lake restoration programme since 1982 has had a significant impact on the formation of the seasonal layers. Results of the partitioning of the variance in the varve thickness measures showed that about two thirds of the variance are unexplained by a climate and trophic state model and that trophic state explains $6 \%$, whereas climate accounts for about $28 \%$ of the variance before the effect of lake restoration had a strong impact on the varves. Among the climate parameters the amount of annual precipitation is a strong predictor for explaining the thickness of both dark layer and total couplet thickness, whereas summer precipitation is important for the thickness of the light layer.
\end{abstract}

\section{Introduction}

Lake sediments store a variety of different environmental signals. Annually laminated sediments, so-called varves, provide an unique environmental archive as they permit the highest time-resolution in sediment studies; they even allow a distinction between the sediment deposited during the warm and the cold season of a year. Furthermore, varves provide an exact chronology in sidereal years, independent of radiometric methods such as ${ }^{137} \mathrm{Cs},{ }^{210} \mathrm{~Pb}$, or ${ }^{14} \mathrm{C}$-dating.

Seasonal cycles in sedimentation are a basic prerequisite for the formation of varves. Varve preservation may depend on different factors such as a high sedimentaccumulation rate or the lack of bioturbation that leads to an averaging of the environmental signal in the sediment by an unknown and often varying factor 
(Davis, 1974). Depending on the location as well as on the geology and geomorphology of the hydrological catchment of a lake, different types of varves may be formed (see, e.g., Sturm, 1979; O'Sullivan, 1983; Sturm and Lotter, 1995).

Studies in connection with glacial-fed lake systems suggest a positive correlation between summer temperatures and thickness of clastic varves (e.g. Perkins and Sims, 1983; Leonard, 1986; Wolfe and Teller, 1993; Desloges, 1994; Leemann and Niessen, 1994; Hardy et al., 1996). In biochemically controlled aquatic systems, however, the relationship between climate and varve formation is more complex. The summer layer of a varve may provide an indirect measure of climate. In the marine environment, for example, climatically controlled varve formation in relation to El Niño Southern Oscillation events has been observed (e.g. Schimmelmann et al., 1990). In lakes, several studies have suggested some relationship between climate and varve formation (Renberg et al., 1984; Goslar, 1989; Boryczka et al., 1989; Zolitschka, 1992, 1996; Itkonen and Salonen, 1994). Given a precise chronology, a direct comparison of instrumental meteorological time-series and varve features may yield information about the climatic parameters influencing varve formation. A better understanding of the modern processes that lead to distinctive varve features can help to decipher long varve chronologies in terms of past climate. Nevertheless, it has to be borne in mind that the available instrumental records cover the time during which significant anthropogenic eutrophication of lakes has also taken place. Many lakes have developed varved sediments as a result of considerable increases in nutrient loadings during the last 50-100 years. Therefore, it is important to try to disentangle the trophic signal from the climatic signal in varved sediments.

Our study at Baldeggersee was undertaken to estimate the influence of the climatic signal on modern bio-chemical varve formation, to consider the influence of nutrient loadings on varve formation, and to quantify the relative roles of climate and nutrients on varve thickness.

\section{Site and methods}

Baldeggersee is situated on the central Swiss Plateau at $463 \mathrm{~m}$ a.s.l. $\left(47^{\circ} 10^{\prime} \mathrm{N}, 8^{\circ} 17^{\prime}\right.$ E, see Fig. 1). The lake has a volume of $0.173 \mathrm{~km}^{3}$ and a surface of $5.2 \mathrm{~km}^{2}$. Its catchment includes $73 \mathrm{~km}^{2}, 77 \%$ of which consists of intensively used agricultural land, $12 \%$ forest, $5 \%$ urban areas, and $6 \%$ lake surface (Stadelmann et al., 1994). Maximum and mean depths are $66 \mathrm{~m}$ and $33 \mathrm{~m}$, respectively. The mean residence time of the water is 4.3 years. The sediment in the deepest part of the basin is annually laminated back to 1885 A.D., indicating hypolimnetic anoxia since the last century (see also Wehrli et al., 1997). Each varve consists of a light diatom and calcite spring/summer layer followed by a dark organic autumn/winter layer (see Lotter et al., 1997a).

As early as the 1920s Nipkow (1927) discovered and sampled the laminated sediments in Baldeggersee. In an unsuccessful attempt he tried to correlate meteorological features such as precipitation or freezing of the lake with the abundance of planktonic organisms. Niessen and Sturm (1987) mapped the occurrence of laminated sediments within Baldeggersee. They suggested a relationship between increasing $\mathrm{PO}_{4}$ concentrations in the water and increasing grain size of the 


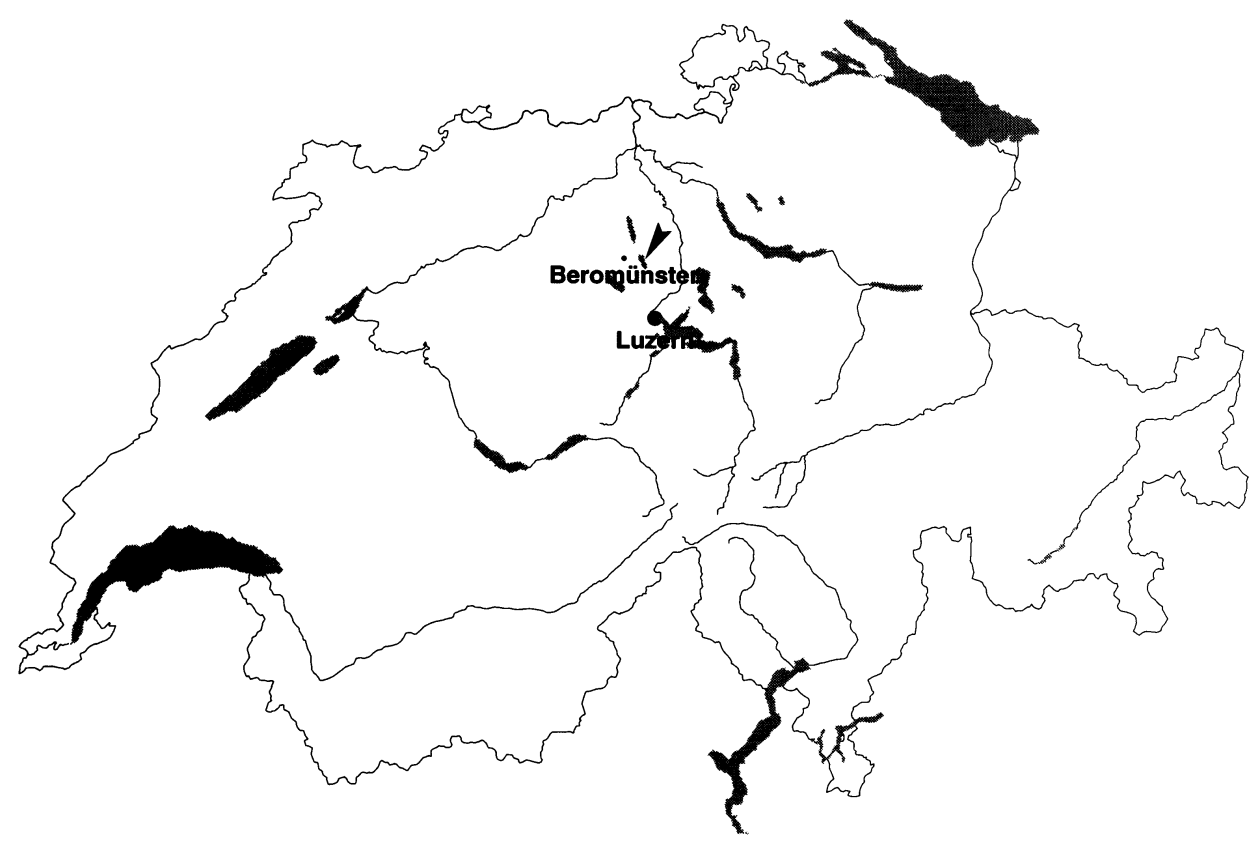

Figure 1. Map of Switzerland indicating the location of Baldeggersee (arrow) and the location of the climate stations Luzern (temperature) and Beromünster (precipitation)

calcite crystals since the beginning of this century, a hypothesis that has been supported by modern varve studies (Lotter et al., 1997a).

Since approximately 1940 the water column below $40 \mathrm{~m}$ has shown summer anoxia and during the peak of eutrophication, at the beginning of the 1970s, the water below $10 \mathrm{~m}$ was anoxic (see Wehrli et al., 1997). As a result of this pollution, the lake has been subjected to a lake restoration programme since 1982: during the summer oxygen and during the winter air is pumped to 3 locations in the deepest part of the basin to enhance water circulation and to fulfil the Swiss quality standard of a minimum of $4 \mathrm{mg} \mathrm{O}_{2} \mathrm{l}^{-1}$ for natural lakes. As a result, oxygen conditions in the water column have improved (Wehrli et al., 1997). Nevertheless, the water/sediment interface in the deepest part is still anoxic, and the varves have been preserved.

The topmost $70 \mathrm{~cm}$ of sediment were sampled in autumn 1993 with a freeze corer (see Lotter et al., 1997b). The varves were identified on sediment thin-sections. The thickness of the dark and light layers were measured repeatedly for the varves deposited between 1885 to 1993 on two different cores (see Lotter et al., 1997a). For the statistical analyses we have utilized the mean layer thickness (light, dark, and total couplet) of two measurements in core BA93-C. Moreover, the thickness of the topmost seven unconsolidated layers (1986-1992) has been detrended according to their water content to allow a better comparison with the underlying, consolidated layers. Because of the availability of the meteorological data, only the period between 1902 and 1992 has been used in the statistical analyses. We have used the 
monthly precipitation values of Beromünster $\left(640 \mathrm{~m}\right.$ a.s.l., $\left.47^{\circ} 12^{\prime} \mathrm{N}, 8^{\circ} 12^{\prime} \mathrm{E}\right)$ and the monthly mean air temperatures for Luzern $\left(498 \mathrm{~m}\right.$ a.s.l., $\left.47^{\circ} 04^{\prime} \mathrm{N}, 8^{\circ} 19^{\prime} \mathrm{E}\right)$ for the period of 1902 to 1992 . Both data-sets have been kindly provided by the Swiss Meteorological Institute.

For the statistical analyes the meteorological time-series have been modified so that each year runs from March to February. This modification seemed appropriate as the varves in Baldeggersee reflect hydrological rather than calendar years: their onset has been defined as the onset of calcite precipitation, occurring between the months of March and May (Sturm and Friedl, pers. comm.).

Phosphorus concentrations in Baldeggersee during spring overturn are available back to the 1950s (see Wehrli et al., 1997 and Fig. 4). For the periods when no water chemistry measurements are available diatom-inferred $\mathrm{P}$ reconstructions have been used (Lotter, in press). The process of lake restoration has been modelled as a binary variable, with 1 for samples from the period between 1982 and 1992 and 0 for samples from the period 1902-1981.

As the detrending of the topmost seven layers as well as the lake restoration since 1982 might limit a direct comparison with the rest of the varve time-series and as the standard deviations of varve measurements below 1920 are higher (see Lotter et al., 1997a) the same statistical analyses were repeated for the time-series between 1920 to 1980.

Statistical analyses were performed in an attempt to answer the following questions: (1) which of the various climatic and limnological variables, considered separately, explain, in a statistical sense, a significant amount of variation in the three thickness measures considered together (light layer, dark layer, total couplet); (2) which combination of variables best explains the variation in the thickness of the layers when each thickness measure is considered separately; (3) which subset of the climatic and limnological variables best explains the variation in the three thickness measures when considered together; and (4) what proportions of the total variance in the thickness measures are explained by climate, by nutrient status, and by nutrient status covarying temporally with climate, and what proportion of the variance is unexplained by these variables. These questions were asked of the two time-series, 1902-1992 and 1920-1980.

In all the analyses the thickness measures are considered as response or dependent variables, whereas the climatic (temperature, precipitation) and limnological variables (phosphorus, lake-restoration) are treated as predictor or explanatory variables. With only one response variable the statistical technique used is multiple linear regression (question 2). When there are three response variables (questions 1, 3, 4), we used redundancy analysis (RDA, ter Braak, 1994), also known as leastsquares reduced-rank regression (ter Braak and Looman, 1994). These linear-based techniques were used because of the limited range of variation in the response variables and the linear, or at least monotonic, relationships between the response and the predictor variables. Selection of predictor variables (questions 2 and 3) was achieved by means of a forward-selection procedure (Escoufier and Robert, 1979; ter Braak, 1990). At each step the predictor variable is selected that adds the most to the explained variance of the response variables, and the statistical significance of the variable to be added is assessed by means of a restricted Monte Carlo permutation test (ter Braak, 1990). As the data show strong temporal autocorrelation, 
thereby rendering statistical assessment of relationships difficult and potentially misleading, the time-series were detrended first by partialling out the age of each layer as a covariable (ter Braak, 1990, 1994).

Partitioning of the variance in the varve-thickness data in terms of climate, nutrient status, and the covariance between climate and nutrient status was done by a series of RDAs and partial RDAs following the procedure of Borcard et al. (1992). In these series the variance is partitioned into four components: (1) variance due to the climatic variables independent of nutrient status and age; (2) variance due to nutrient status independent of climate and age; (3) covariance between climate and nutrient status independent of age; and (4) unexplained variance. Some of these components can be negative (Whittaker, 1984), although with stratigraphical palaeoecological data this rarely occurs. Roy et al. (1994) and Cattaneo et al. (1993) provide recent examples of the use of the variance partitioning approach in limnology.

All statistical analyses were carried out using the program CANOCO 3.12 (ter Braak, 1987-1992).

\section{Results and discussion}

The formation of seasonal layers may be influenced by different climatic and limnological factors. As there is a close relationship between air temperature and surface-water temperature (Forester, 1987; Livingstone and Schanz, 1994; Livingstone and Lotter, 1997) and as long water temperature time-series are not available we have used air temperatures to characterize the thermic component of the climate.

The thicknesses of the light and dark layers show a low correlation between themselves but a high positive correlation with the thickness of the total layer (Table 1). The light calcite spring/summer layers are generally thicker than the dark organic autumn/winter layers (Fig. 2).

Table 1. Correlation coefficients between the thickness of the light, dark, and total layers in core BA93-C for the periods of 1902-1992 (detrended time-series) and 1920-1980

\begin{tabular}{lllllllll}
\hline & \multicolumn{2}{l}{$1992-1902: \mathrm{n}=91$} & & & \multicolumn{2}{l}{$1980-1920: \mathrm{n}=61$} & \\
\cline { 2 - 4 } \cline { 7 - 8 } & light & dark & total & & & light & dark & total \\
\hline light layer & 1.0 & 0.286 & 0.785 & & 1.0 & $0.224 *$ & 0.779 \\
dark layer & - & 1.0 & 0.818 & & - & 1.0 & 0.786 \\
total layer & - & - & 1.0 & & - & - & 1.0 \\
\hline
\end{tabular}

All correlations (Bonferroni-adjusted probabilities) significant at the $2.5 \%$ level, except*.

To get an idea which environmental variables have an influence on the formation of the layers a series of exploratory RDAs were carried out for each predictor variable separately (Table 2). For both periods of analysis annual precipitation explains the highest statistically significant portions of the variance in the varve data and in the longer series (1902-1992) followed by lake restoration. Summer tem- 


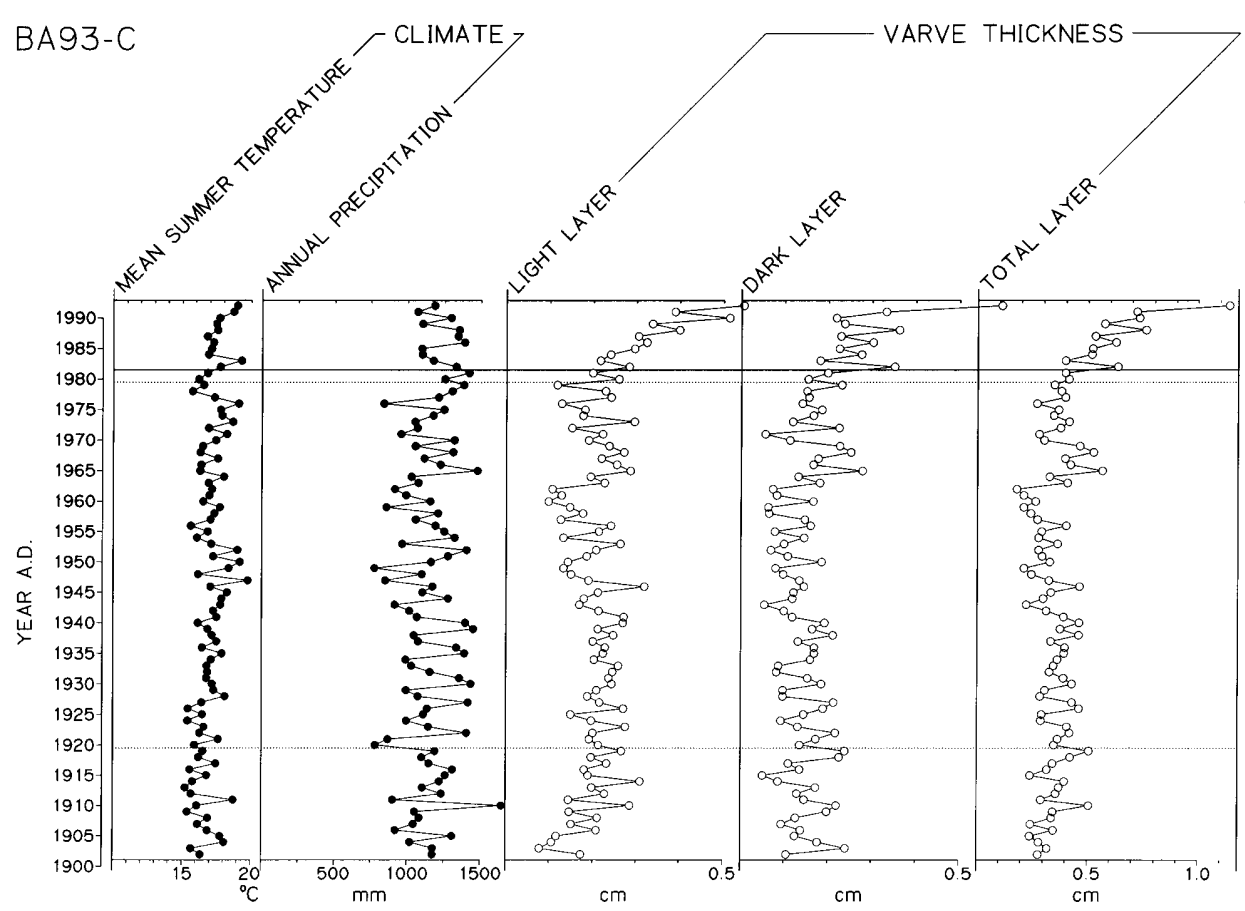

Figure 2. Time-series of mean summer temperatures, annual precipitation, undetrended thickness of light, dark and total layers for the period of 1902-1992. Thick horizontal line indicates the onset of lake restoration in 1982; dotted horizontal lines mark the period of 1920-1980 used in the statistical analyses

perature as well as precipitation during the months of May to July are also important as explanatory variables.

A comparison of correlation coefficients carried out between the layer measurements and the average temperature and sum of precipitation for each month (Fig. 3) indicates positive significant correlations at the 5\% level between the thickness of the light layer and the sum of precipitation during the months of May to July for both investigated periods. This correlation can be explained by input of additional nutrients and carbonate from the catchment thus allowing further biogenic calcite precipitation pulses during summer. February and November temperature and precipitation correlate positively with the thickness of the dark layer which is likely the effect of temperature-enhanced productivity during exceptionally warm winter months in connection with higher precipitation that brings additional nutrients to the lake.

A multiple linear regression with forward selection of variables was carried out for all three response variables (light, dark, and total layer thickness) separately. The results (Table 3) suggest that summer and September precipitation explain over $20 \%$ of the variance in the thickness of the light layer, whereas the thickness of the dark layer depends more on annual precipitation and on phosphorus concentration. 
Table 2. Results of partial redundancy analyses (RDA) using the thickness measurements of light, dark, and total layers as response variables and age as a covariable

\begin{tabular}{lcc}
\hline Predictor & $\begin{array}{l}\text { \% variance explained after } \\
\text { age is fitted as a covariable }\end{array}$ & $\begin{array}{l}\text { \% variance explained after } \\
\text { age is fitted as a covariable } \\
1902-1992 \text { (detrended) }\end{array}$ \\
$1920-1980$
\end{tabular}

* significant at the $5 \%$ level.

Temp. $=$ temperature, Prec. $=$ precipitation

Besides limnological variables ( $\mathrm{P}$ concentration, restoration), the thickness of the total layer is best modelled by annual precipitation and summer temperature.

A RDA with forward selection using all three varve response variables indicates (Table 4) that annual precipitation, temperature during the growing season (summer and August temperatures), and limnological variables (restoration, $\mathrm{P}$ concentration) explain more than one third of the variance in the thickness of the single layers. 
1992-1902: Temperatures

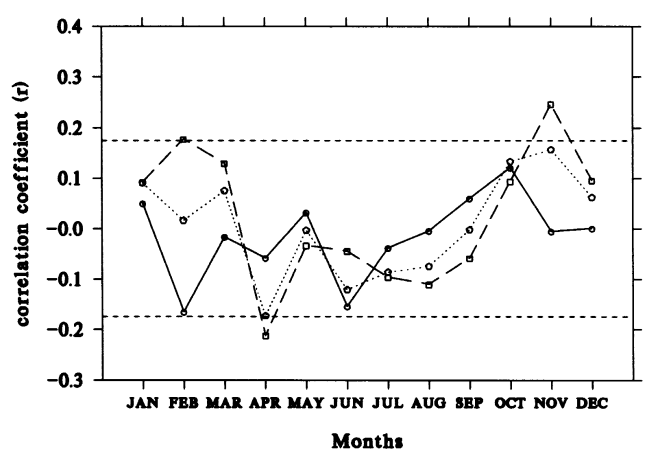

1980-1920: Temperatures

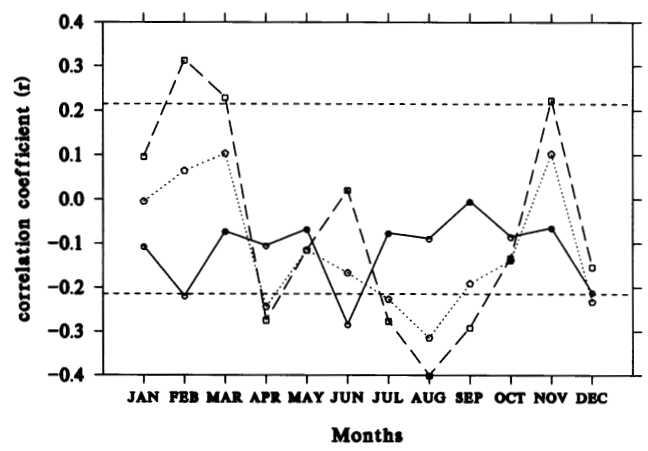

Precipitation

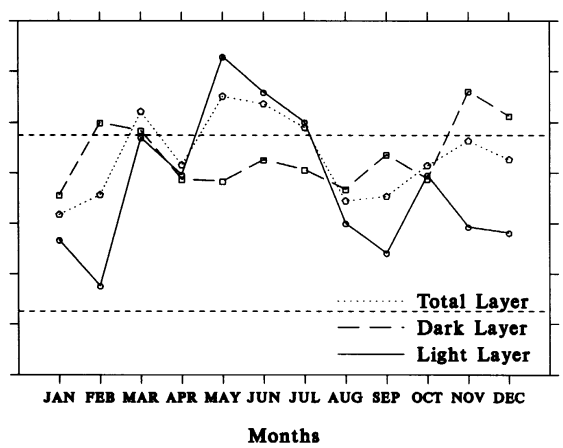

Precipitation

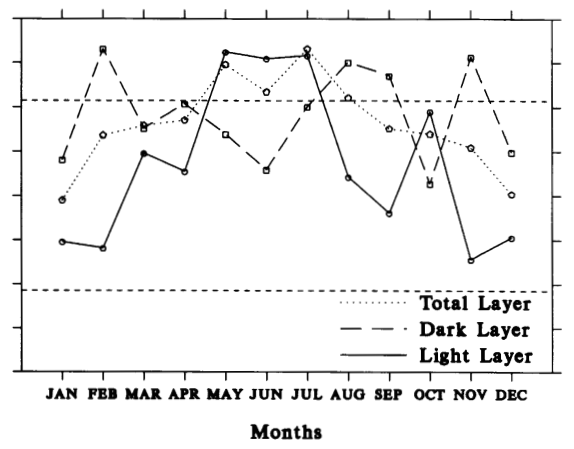

Figure 3. Correlation coefficients for thickness of total, dark, and light layers compared to mean monthly temperatures (Luzern) and sum of monthly precipitations (Beromünster) for the two investigated periods. Dashed horizontal lines indicate the $5 \%$ significance levels

Based on these results we have tried to partition the variance in the varve dataset remaining after age is partialled out as a covariable (Table 5). The variables Summer temperature and Annual precipitation, explaining the highest portion of variance among the climate data (Table 2), were chosen to represent "climate", whereas $\mathrm{P}$ concentration and presence or absence of restoration are used to characterize the "trophic state" of Baldeggersee. For both time periods the variance unexplained by climate and trophic state accounts for about two thirds of the total variance in the varve data after age is partialled out (see Table $5 \mathrm{~b}$ ). In the time series of 1902-1992 the remaining one third of the variance is explained by $17.6 \%$ of climate independent of trophic state and time, by $17.6 \%$ of the trophic state independent of climate and time, and by $1.3 \%$ variance due to climate covarying with trophic state. In the shorter data set of 1920-1980 climate independent of trophic state explains $28.1 \%$, whereas trophic state (in this case only P concentration) accounts for $5.9 \%$ of the total variance after age is partialled out as a covariable. 
Table 3. Results of partial multiple linear regression analysis of single response variables in relation to predictor variables chosen by a forward-selection procedure

\begin{tabular}{|c|c|c|c|c|c|}
\hline Time & Variable & Covariable & Predictors & $\mathrm{r}$ & $\begin{array}{l}\% \text { variance after } \\
\text { age is fitted as } \\
\text { a covariable }\end{array}$ \\
\hline $1902-1992$ & light layer & age & $\begin{array}{l}\text { Summer Prec. } \\
\text { Restoration } \\
\text { September Prec. }\end{array}$ & 0.492 & 24.2 \\
\hline $1920-1980$ & light layer & age & $\begin{array}{l}\text { Summer Prec. } \\
\text { September Prec. }\end{array}$ & 0.454 & 20.6 \\
\hline $1902-1992$ & dark layer & age & $\begin{array}{l}\text { Annual Prec. } \\
\text { Restoration } \\
\text { P concentration }\end{array}$ & 0.588 & 34.6 \\
\hline $1920-1980$ & dark layer & age & $\begin{array}{l}\text { Annual Prec. } \\
\text { August Temp. } \\
\text { November Prec. } \\
\text { P concentration } \\
\text { February Temp. }\end{array}$ & 0.778 & 60.5 \\
\hline $1902-1992$ & total layer & age & $\begin{array}{l}\text { Annual Prec. } \\
\text { Restoration } \\
\text { Summer Temp. }\end{array}$ & 0.635 & 40.2 \\
\hline $1920-1980$ & total layer & age & $\begin{array}{l}\text { Annual Prec. } \\
\text { P concentration } \\
\text { December Temp. } \\
\text { August Temp. }\end{array}$ & 0.669 & 44.7 \\
\hline
\end{tabular}

Temp. $=$ temperature, Prec. $=$ precipitation, $r=$ correlation between the predictor and the response variables.

Table 4. Results of partial redundancy analyses (RDA) with forward selection of predictor variables, thickness measurements of light, dark, and total layer as response variables, and age as a covariable

\begin{tabular}{llllll}
\hline Time & Variable & Covariable & Predictors & r & $\begin{array}{l}\text { \% variance after } \\
\text { age is fitted as } \\
\text { a covariable }\end{array}$ \\
\hline $1902-1992$ & $\begin{array}{l}\text { light, dark, } \\
\text { total layer }\end{array}$ & age & $\begin{array}{l}\text { Annual Prec. } \\
\text { Restoration } \\
\text { Summer Temp. }\end{array}$ & 0.640 & 33.9 \\
1920-1980 & $\begin{array}{l}\text { light, dark, } \\
\text { total layer }\end{array}$ & age & $\begin{array}{l}\text { Annual Prec. } \\
\text { P concentration } \\
\text { August Temp. } \\
\text { December Temp. }\end{array}$ & 0.692 & 39.5 \\
& & & \\
\end{tabular}

Temp. $=$ temperature, Prec. $=$ precipitation, $\mathrm{r}=$ correlation between the predictor and the response variables. 
Table 5a. Partitioning of the variance in the varves of Baldeggersee core BA93-C

\begin{tabular}{|c|c|c|c|c|c|}
\hline Time & $\begin{array}{l}\text { Response } \\
\text { variable }\end{array}$ & Covariable & Predictors & $\%$ variance & $\begin{array}{l}p \text { after age } \\
\text { is fitted as } \\
\text { covariable }\end{array}$ \\
\hline $1902-1992$ & $\begin{array}{l}\text { light, dark, } \\
\text { total layer }\end{array}$ & age & Restor & 15.7 & $0.01 *$ \\
\hline $1902-1992$ & $\begin{array}{l}\text { light, dark, } \\
\text { total layer }\end{array}$ & age & Restor $+\mathrm{P}$ conc & 18.9 & $0.01 *$ \\
\hline $1902-1992$ & $\begin{array}{l}\text { light, dark, } \\
\text { total layer }\end{array}$ & age & $\mathrm{P}$ conc & 0.8 & 0.67 \\
\hline $1920-1980$ & $\begin{array}{l}\text { light, dark, } \\
\text { total layer }\end{array}$ & age & P conc & 5.1 & $0.03 *$ \\
\hline $1902-1992$ & $\begin{array}{l}\text { light, dark, } \\
\text { total layer }\end{array}$ & age & SumT & 6.8 & $0.01 *$ \\
\hline $1920-1980$ & $\begin{array}{l}\text { light, dark, } \\
\text { total layer }\end{array}$ & age & SumT & 10.3 & $0.02 *$ \\
\hline $1902-1992$ & $\begin{array}{l}\text { light, dark, } \\
\text { total layer }\end{array}$ & age & AnnP & 16.9 & $0.01 *$ \\
\hline $1920-1980$ & $\begin{array}{l}\text { light, dark, } \\
\text { total layer }\end{array}$ & age & AnnP & 23.6 & $0.01 *$ \\
\hline $1902-1992$ & $\begin{array}{l}\text { light, dark, } \\
\text { total layer }\end{array}$ & age & SumT + AnnP & 18.9 & $0.01 *$ \\
\hline $1920-1980$ & $\begin{array}{l}\text { light, dark, } \\
\text { total layer }\end{array}$ & age & SumT + AnnP & 27.3 & $0.01 *$ \\
\hline $1902-1992$ & $\begin{array}{l}\text { light, dark, } \\
\text { total layer }\end{array}$ & age + SumT + AnnP & P conc + Restor & 21.7 & $0.01 *$ \\
\hline $1920-1980$ & $\begin{array}{l}\text { light, dark, } \\
\text { total layer }\end{array}$ & age + SumT + AnnP & $\mathrm{P}$ conc & 8.1 & $0.01 *$ \\
\hline $1902-1992$ & $\begin{array}{l}\text { light, dark, } \\
\text { total layer }\end{array}$ & age $+\mathrm{P}$ conc + Restor & SumT + AnnP & 21.7 & $0.01 *$ \\
\hline $1920-1980$ & $\begin{array}{l}\text { light, dark, } \\
\text { total layer }\end{array}$ & age $+\mathrm{P}$ conc & SumT + AnnP & 29.6 & $0.01 *$ \\
\hline $1902-1992$ & $\begin{array}{l}\text { light, dark, } \\
\text { total layer }\end{array}$ & age & $\begin{array}{l}\text { P conc }+ \text { Restor } \\
+ \text { sumT }+ \text { AnnP }\end{array}$ & 36.6 & $0.01 *$ \\
\hline $1920-1980$ & $\begin{array}{l}\text { light, dark, } \\
\text { total layer }\end{array}$ & age & $\begin{array}{l}\mathrm{P} \text { conc }+ \text { sumT } \\
+ \text { AnnP }\end{array}$ & 33.2 & $0.01 *$ \\
\hline
\end{tabular}

* significant at the $5 \%$ level.

SumT = summer temperature; AnnP = annual precipitation; $\mathrm{P}$ conc $=$ phosphorus concentration; $\mathrm{p}=$ exact Monte Carlo probability.

Table 5b. Results of the variance partitioning in Baldeggersee core BA93-C using climate (summer temperature and annual precipitation) and trophic state ( $\mathrm{P}$ concentration and restoration) as models. This partitioning is of the residual variance remaining after age is fitted as a covariable

\begin{tabular}{lll}
\hline & $1992-1902$ & $1980-1920$ \\
\hline Total variance & 140.26 & 70.03 \\
Total residual variance after fitting age as a covariable & 127.36 & 69.40 \\
Unexplained variance & $63.44 \%$ & $66.81 \%$ \\
Climate effects independent of trophic state & $17.62 \%$ & $28.05 \%$ \\
Trophic state independent of climate effects & $17.62 \%$ & $5.85 \%$ \\
Covariance between the effect of climate and trophic state & $1.32 \%$ & $-0.71 \%$ \\
after the effects of age have been partialled out as a covariable & & \\
\hline
\end{tabular}


The differences in the results between the period including the effect of restoration (1902-1992) and the pre-restoration time (1920-1988) as well as the significance of the restoration variable in the 1902-1992 time-series suggest that lake restoration has had an important effect on the thickness of the seasonal layers and therefore also on the formation of the varves. The $\mathrm{P}$ concentration, on the other hand, is an important explanatory variable for the dark layer. The sediments not only change their visible appearance but the accumulation rates also changed. The artificial mixing of Baldeggersee since 1982 may have led to an enhanced cycling of nutrients within the water column which, in turn, augmented bioproductivity and resulted in higher biomass accumulation (see Lotter et al., 1997a).

Annual precipitation and summer temperatures have the highest explanatory power for the variance in the thickness of the dark layer (see Tables 2 and 3 ). These variables have thus been used to calculate 11-year running correlation coefficients (Dean and Anderson, 1974). The correlation coefficients for the dark-layer thickness in relation to summer temperature show a significant negative correlation at the $5 \%$ level for the period between the mid-1950s and the mid-1970s (Fig. 4).

Total Phosphorus

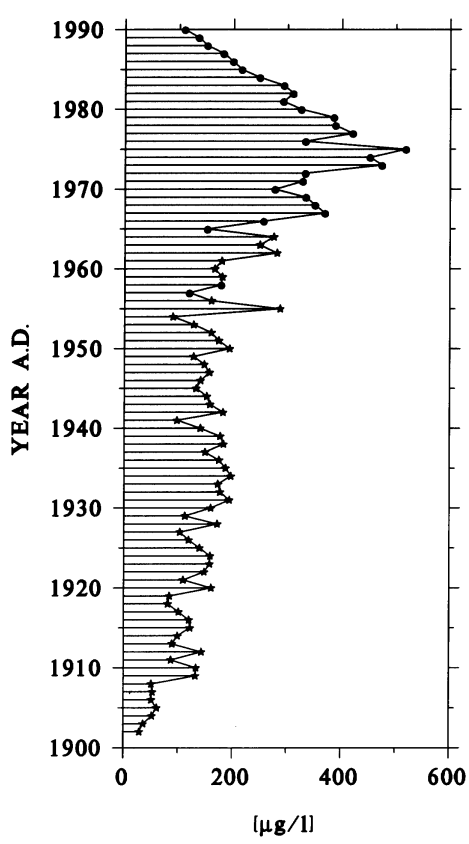

Climate Indices

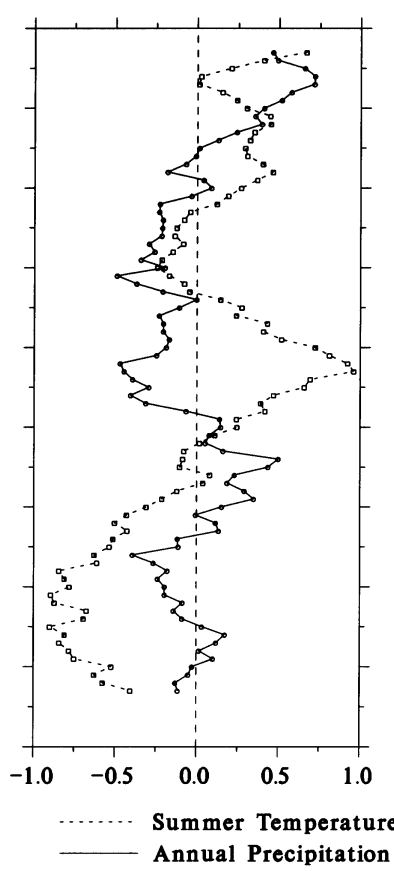

\section{Dark Layers}

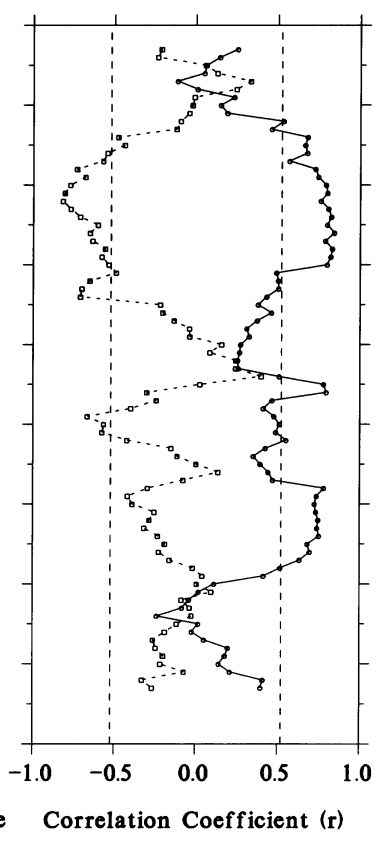

Figure 4. Average total phosphorus concentration for Baldeggersee during spring circulation (dots show measured values, stars indicate diatom-inferred reconstructions, see Lotter, in press); standardized smoothed (11-years running mean) values for summer temperature (Luzern) and annual precipitation (Beromünster); and 11-year running correlation coefficients between dark layers, summer temperatures and annual precipitation. The dashed lines indicate the $5 \%$ significance levels 
The relationship between the dark-layer thickness and annual precipitation shows significant positive correlations from the early 1920s to the early 1930s as well as between 1960 and the late 1970s (Fig. 4). Comparison of these running correlation coefficients with 11-years running means for the standardized mean summer temperature and the standardized sum of annual precipitation for the period of 1902-1992 (Fig. 4) shows no linear relationship. Wetter years such as between the mid-1920s and 1940, on the one hand, produce a positive correlation between darklayer thickness and annual precipitation, which may be an effect of the input of additional nutrients from the catchment. Drier years with colder summers, on the other hand, such as between the late 1950s and the late 1960s show, as expected, a negative correlation between dark layers and summer temperatures. Lower summer temperatures may reduce aquatic productivity which would result in a lower organic deposition. The positive correlation between dark layers and annual precipitation, however, seems to be controlled by additional factors other than the amount of precipitation. The increasing phosphorus concentrations (Fig. 4) in Baldeggersee during this time suggest that the nutrient loading in the lake was high enough to be independent of additional nutrients via precipitation. Once the phosphorus concentration decreased, since the mid-1970s, the correlations of both summer temperature and annual precipitation start to approach 0 . The dry years and warm summers between the 1940s and the mid-1950s led to a drastic change in the relationship between dark layers and summer temperatures.

\section{Conclusions}

Based on the results of the different statistical analyses we conclude that the explanatory variables used in this study only explain about a third of the variance in the varve-thickness data. Other factors that were not included in the analyses such as radiation, wind, mixing of the water column, phytoplankton biomass and resuspension of littoral sediment may also have strong influences on the formation and thickness of varves.

The formation of the light calcite layers is influenced by summer precipitation, whereas the sedimentation of the dark organic layers depends on annual precipitation as well as on P concentration (see Lotter et al., 1997 a). Precipitation explains more of the variance than temperature for both periods of analysis and for all types of layers. Higher annual and summer precipitation will, on the one hand, wash additional nutrients from the intensively used agricultural land into the lake which may, in turn, augment the algal biomass. The dead biomass will then accumulate in the dark layers. On the other hand, during summer, after the first biogenic calcite deposition, precipitation may supply additional nutrients and calcium carbonate from the catchment required for further pulses of biogenic calcite precipitation. Recent sediment trap studies in Baldeggersee support this hypothesis (Sturm and Friedl, pers. comm.).

\section{ACKNOWLEDGEMENTS}

We thanks S. Juggins and an anonymous reviewer for valuable comments on an earlier version of the manuscript. This work was supported by Swiss National Science Foundation through National 
Research Program 31 project 4031-33147 and Priority Programme Environment project 5001-34876 and is a contribution to the IGCP 374 project "Palaeoclimatology and palaeoceanography from late Quaternary and Holocene laminated sediments".

\section{REFERENCES}

Borcard, D., P. Legendre and P. Drapeau, 1992. Partialling out the spatial component of ecological variation. Ecology 73:1045-1055.

Boryczka, J., K. Wieckowski and B. Wicik, 1989. Holocene climatic changes in the light of statistical analysis of laminated sediments from the Gosciaz lake. Zeszyty Naukowe Politechniki Slaskiej Mathematyka-Fizyka 57, Geochronometria 5:65-75.

Cattaneo A., P. Legendre and T. Niyonsenga, 1993. Exploring periphyton unpredictability. Journal of North American Benthological Society 12:418-430.

Davis, R. B., 1974. Stratigraphic effects of tubificids in profundal lake sediments. Limnology and Oceanography 19:466-487.

Dean, W. E. and R. Y. Anderson, 1974. Application of some correlation coefficient techniques to time-series analysis. Mathematical Geology 6:363-372.

Desloges, J. R., 1994. Varve deposition and the sediment yield at three small lakes of the southern Canadian Cordillera. Arctic and Alpine Research 26:130-140.

Escoufier, Y. and P. Robert, 1979. Choosing variables and metrics by optimising the RV-coefficient. In Rustagi, J. (ed.), Optimising Methods in Statistics. Academic Press, New York. $205-219$.

Forester, R. M., 1987. Late Quaternary paleoclimate records from lacustrine ostracods. In Ruddiman, W. F. and H. E. Wright (eds.), North America and adjacent oceans during the last deglaciation. The Geology of North America. Boulder, Colorado. Geological Society of America, $261-276$.

Goslar, T., 1989. Variations of the ratio of laminae thickness in sediments of lake Gosciaz - a comparison with some palaeotemperature estimates. Zeszyty Naukowe Politechniki Slaskiej Matematyka-Fizyka 57, Geochronometria 5:21-28.

Hardy, D. R., R. S. Bradley and B. Zolitschka, 1996. The climatic signal in varved sediments from Lake C2, northern Ellesmere Island, Canada. Journal of Paleolimnology 16:227-238.

Itkonen, A. and V. P. Salonen, 1994. The response of sedimentation in three varved lacustrine sequences to air temperatures, precipitation and human impact. Journal of Paleolimnology $11: 323-332$.

Leemann, A. and F. Niessen, 1994. Varve formation and the climatic record in an Alpine proglacial lake: calibrating annually-laminated sediments against hydrological and meteorological data. The Holocene 4:1-8.

Leonard, E. M., 1986. Varve studies at Hector lake, Alberta, Canada, and the relationship between glacial activity and sedimentation. Quat. Res. 25:199-214.

Livingstone, D. M. and F. Schanz, 1994. The effects of deep-water siphoning on a small, shallow lake: a long-term case study. Arch. Hydrobiol. 132:15-44.

Livingstone, D. M. and A. F. Lotter, 1997. The relationship between air and water temperatures in lakes of the Swiss Plateau: a case study with palaeolimnological implications. Journal of Paleolimnology: in press.

Lotter, A. F. The recent eutrophication of Baldeggersee (Switzerland) as assessed by fossil diatoms assemblages. The Holocene, in press.

Lotter, A. F., M. Sturm, J. L. Teranes and B. Wehrli, 1997 a. Varve formation since 1885 and highresolution varve analyses in hypertrophic Baldeggersee (Switzerland). Aquatic Sciences, $304-325$.

Lotter, A. F., I. Renberg, H. Hansen, R. Stöckli and M. Sturm, 1997b. A remote controlled freeze corer for sampling unconsolidated surface sediments. Aquatic Sciences, 295-303.

Niessen, F. and M. Sturm, 1987. Die Sedimente des Baldeggersees (Schweiz) - Ablagerungsraum und Eutrophierungsentwicklung während der letzten 100 Jahre. Arch. Hydrobiol. 108: 365-383.

Nipkow, F., 1927. Über das Verhalten der Skelette planktischer Kieselalgen im geschichteten Tiefenschlamm des Zürich- und Baldeggersees. Ph.D thesis ETH Zürich. 
O'Sullivan, P. E., 1983. Annually-laminated lake sediments and the study of Quaternary environmental changes - a review. Quaternary Science Reviews 1:245-313.

Perkins, J. A. and J. D. Sims, 1983. Correlation of Alaskan varve thickness with climatic parameters, and use in paleoclimatic reconstruction. Quaternary Research 20:308-321.

Renberg, I., U. Segerström and J.-E. Wallin, 1984. Climatic reflection in varved lake sediments. In Mörner, N.-A. and W. Karlén (eds.), Climatic changes on a Yearly to Millennial Basis. Reidel, 249-256.

Roy, R., P. Legendre, R. Knowles and M. N. Charlton, 1994. Denitrification and methane production in sediment of Hamilton Harbour (Canada). Microbial Ecology 27:123-141.

Schimmelmann, A., C. B. Lange and W. H. Berger, 1990. Climatically controlled marker layers in Santa Barbara Basin sediments and fine-scale core-to-core correlation. Limnol. Oceanogr. $35: 165-173$.

Stadelmann, P., P. Herzog, P. Arnold, J. C. Bernegger, E. Butscher, F. Hirsiger and P. Koller, 1994. Sanierung des Baldegger- und Hallwilersees und deren Einzugsgebiete. Situationsanalyse und Rechenschaftsbericht zuhanden des Gemeineverbandes Baldegger- und Hallwilersee. Luzern, Kantonales Amt für Umweltschutz.

Sturm, M., 1979. Origin and composition of clastic varves. In Schlüchter, C. (ed.), Moraines and Varves, 281-285.

Sturm, M. and A. F. Lotter, 1995. Seesedimente als Umweltarchive. Archimedes 50:4-8.

ter Braak, C.J.F., 1987-1992. CANOCO - a FORTRAN program for canonical community ordination. Ithaca, New York, Microcomputer Power, 95 pp.

ter Braak, C. J. F., 1990. Update notes: CANOCO version 3.10. Agricultural Mathematics Group, Wageningen, $35 \mathrm{pp}$.

ter Braak, C. J. F., 1994. Canonical community ordination. Part I. Basic theory and linear methods. Ecoscience 1:127-140.

ter Braak, C. J.F. and C.W. N. Looman, 1994. Biplots in reduced-rank regression. Biometrical Journal 36:983-1003.

Wehrli, B., A. F. Lotter, T. Schaller and M. Sturm, 1997. High-resolution varve studies in Baldeggersee (Switzerland): project overview and limnological background data. Aquatic Sciences, 59:285-294.

Whittaker, J., 1984. Model interpretation from additive elements of the likelihood function. Applied Statistics 33:52-64.

Wolfe, B. and J. T. Teller, 1993. Sedimentological and stratigraphic investigations of a sequence of 106 varves from glacial Lake Assiniboine, Saskatchewan. Journal of Paleolimnology 9: $257-273$.

Zolitschka, B., 1992. Climatic change evidence and lacustrine varves from maar lakes, Germany. Climate Dynamics 6:229-232.

Zolitschka, B., 1996. High resolution lacustrine sediments and their potential for palaeoclimatic reconstruction. In Jones, P. D., R. S. Bradley and J. Jouzel (eds.), Climatic Variations and Forcing Mechanisms of the Last 2000 Years. NATO ASI Series I 41:453-478.

Received 8 January 1997;

revised manuscript accepted 17 July 1997. 